\title{
Significant Effect of the Central Bank Digital Currency on the Design of Monetary Policy
}

\author{
Muhammad Edhie Purnawan ${ }^{\mathrm{a}, *}$, \& Retno Riyanti ${ }^{\mathrm{a}}$ \\ ${ }^{a}$ Universitas Gadjah Mada, and Bank Indonesia Supervisory Board \\ ${ }^{b}$ Bank Indonesia Supervisory Board
}

\begin{abstract}
Entering the millennial era, technology has taken a big role in most sectors of life, including the currency as a product that can only be issued by the central bank. This paper examines the significant effect of central bank digital currency (CBDC) on the design of central bank monetary policy. The paper then sets out some benchmark central bank digital currency (CBDC) in several countries. Many central banks are actively exploring the initiation of sovereign digital currencies. Primary results this study is CBDC providing new monetary instruments, CBDC can improve financial inclusion, and CBDC is potential improvements in monetary policy transmission.
\end{abstract}

Keywords: central bank; digital currency; monetary policy; central bank digital currency; monetary instrument

JEL Classification: E400; E420; E5320 id.

${ }^{*}$ Corresponding Author: Universitas Gadjah Mada, Yogyakarta. E-mail: edhiepurnawan@ugm.ac. 


\section{Introduction}

Commodity money is vulnerable to problems of informational asymmetries and adverse selection, especially in times of frequent devaluations. A theoretical model in the spirit of Shin (1996) and Chwe (1999) where such informational problems reverberate through mutual distrust so as to constitute a severe impediment to the efficiency of exchange. During the past decade there have been continuous developments in financial technology as consumers shift towards online and mobile financial services (Wadsworth, 2018). Many things can be used as a medium of exchange in economic transactions, the most common is the currency, i.e. banknotes or coins. The new technology era, known as digital currency and crypto currency, provide more benefits for no cost administrative services, without intermediaries, without delay. Cryptocurrency although development is very significant but not many countries legalized it as legal tender.

Nowadays technological developments have led to suggestions that a central bank could consider providing digital currency to the public through centralized accounts on its books. Conceptually, this would extend provision of reserves, currently accessible only to certain financial institutions, to the general public. In this case, the central bank can be seen as a "narrow bank" providing accounts to the general public and allowing account holders to use the balances in these accounts to make payments over the central bank's ledger. Alternatively, a central bank could issue a digital currency in a decentralized manner, similar to how physical cash is distributed.

CBDC, at the most basic level, is simply monetary value stored electronically (digitally, or as an electronic token) that represents a liability of the central bank and can be used to make payment Barrdear and Kumhof (2016) and Mersch (2017a). Technology is not an obstacle, but it is not a determining factor when discussing CBDC, either. Therefore, the functional and technical characteristics of CBDC should be determine on the basis of the rationale for the need for CBDC. From the perspective of payments, CBDC could be implemented for example as a digital payment scheme comparable to e-money, which would be directed at consumers and trade. It could also be implemented as a central bank money directed at the financial sector, which would enable real-time securities trading and be connected with blockchain technology-based management of holdings. If CBDC were to be implemented by making central bank accounts available to the public, this would involve the above-mentioned potential implications for bank funding and therefore also for financial stability, for example. These implications should be meticulously analyzed.

\section{Digital Currency and Central Bank Digital Currency}

\subsection{Definition of Money}

Money is the numéraire of the economy and, more importantly, it is the medium of exchange used to meet future payments. In mature monetary economies, money 
has two main features (Fontana, 2004): (1) money has no intrinsic value, and (2) it is universally accepted for trading good and services. Conventional wisdom says that "money is what money does" (Carstens, 2018). That is, money is a unit of account, a means of payment and a store of value. Carolyn Wilkins (2014) also pronounces "They are money because people accept them as money. For this to happen, money must do three things. First, money must serve as a medium of exchange. The alternative is bartering, but that is complicated and inefficient. Second, money must serve as a store of value. Finally, money must serve as a unit of account.

Hicks explained the different roles that money plays in a single-period theory and in a continuation theory (Fontana, 2004: 75). Money is a flow of means of payment that is naturally created during the economic process (especially but not exclusively the production process) and used for the circulation of commodities. Furthermore, in a world of uncertainty, money is also a stock, a store of wealth held to meet unforeseeable payments.

Schnabel and Shin (2018) describe that money is a social convention where one party accepts it as payment bin the expectation that others will do so too. Money denominated in a particular currency (money in a traditional sense) includes money in a physical format (notes and coins, usually with legal tender status) and different types of electronic representations of money, such as central bank money (deposits in the central bank that can be used for payments) or commercial bank money.

Table 1: Money Matrix

\begin{tabular}{|c|c|c|c|c|}
\hline $\begin{array}{l}\text { Unit of ac- } \\
\text { count }\end{array}$ & Means of payment & Issued by & Claim on & $\begin{array}{l}\text { Payment instru- } \\
\text { ment }\end{array}$ \\
\hline \multirow{4}{*}{$\begin{array}{l}\text { National } \\
\text { fiat }\end{array}$} & Cash & Central Bank & Central bank & Cash \\
\hline & $\begin{array}{l}\text { Bank deposit (97-98 } \\
\text { percent of M1) }\end{array}$ & Commercial Bank & $\begin{array}{l}\text { Commercial } \\
\text { Bank }\end{array}$ & $\begin{array}{l}\text { Payment cards, } \\
\text { applications, giro, } \\
\text { cheque }\end{array}$ \\
\hline & E-money & E-money issuer & E-money issuer & $\begin{array}{l}\text { Cards, applica- } \\
\text { tions }\end{array}$ \\
\hline & $\begin{array}{l}\text { Central bank digital } \\
\text { currencies (CBDC) }\end{array}$ & Central bank & Central bank & $?$ \\
\hline Separate & Cryptocurrencies & $\begin{array}{lr}\text { Various } & \text { alter- } \\
\text { natives } & \text { Bitcoin: } \\
\text { miners } & \\
\end{array}$ & $\begin{array}{l}\text { Usually non- } \\
\text { one }\end{array}$ & Applications \\
\hline
\end{tabular}

Source: Schnabel and Shin (2018)

\subsection{Money in Modern Era}

Over the ages, various forms of private money have come and gone. Some have lasted longer than others, but they have given way to central bank money. Financial innovations have allowed people to conduct economic transactions far beyond the constraints imposed by physical currency (Baron et al., 2015). More 
recent technological innovations have allowed users to move away from paperbased exchange systems (such as checks) to electronic systems (such as swiping debit cards through a point-of-sale card reader) to using near-field communication (NFC) technology to enable radio communication through mobile-computing platforms (such as via applications on smartphones) (Baron et al., 2015). As with the 13th-century bills of exchange, these innovations are convenient mechanisms that allow users to use traditional currencies more efficiently. Unlike VCs, they do not constitute new currencies.

The reasons for this resilience of central bank money are of particular interest given current debates about digital currencies - cryptocurrencies and how far they will supplant central bank money. Central Bank Digital Currency is money that is characterized by two features: (1) like banknotes in circulation, CBDC is a claim on the central bank; (2) in contrast to banknotes, it is digital.

The importance of common knowledge is especially relevant in monetary economics in the age of distributed ledger technology (DLT) and Bitcoin, as one interpretation of money is as a score-keeping device on the history of past transactions. The analysis of money as a score-keeping device was given emphasis by the paper by Kocherlakota (1998), whose title is "Money is memory". In the setting of Kocherlakota's analysis, a costless, publicly accessible record of all past transactions that is common knowledge can achieve the allocation with money, and sometimes more. On the other hand, Bhaskar (1998) and Bhaskar et al. (2012) show that such results are not robust to small departures from the common knowledge of infinite histories of transactions. This is so even if the record-keeping device is costless. The current debates about the role of DLT and whether it will displace central bank money thus crucially depend on how important common knowledge is for monetary exchange and how well DLT can recreate the pre-conditions for common knowledge.

Electronic money (e-money), defined in the CPMI's A glossary of terms used in payments and settlement systems as "value stored electronically in a device such as a chip card or a hard drive in a personal computer", is also commonly used around the world. Some jurisdictions have developed specific legislation regulating e-money (e.g. the E-Money Directive in the EU). E-money balances according to the legislation applicable in a particular jurisdiction (e-money in a narrow sense) are usually denominated in the same currency as central bank or commercial bank money and can easily be exchanged at par value for them or redeemed in cash. Since the mid-1990s, the CPMI has studied the development of e-money and the various policy issues associated with it (Bank for International Settlements (BIS), 1996). These categories (cash, central or commercial bank money, and e-money in a narrow sense) are traditionally perceived as "money" in a specific currency, giving rise to a currency's single character (CPMI, 2003).

Digital currency definition according to the international institutions:

European Central Bank (2012): “a virtual currency is a type of unregulated, digital money, which is issued and usually controlled by its developers, and used and accepted among the members of a specific virtual community." 
Financial Action Task Force (2014): "Virtual currency is a digital representation of value that can be digitally traded and functions as (1) a medium of exchange; and/or (2) a unit of account; and/or (3) a store of value, but does not have legal tender status (i.e., when tendered to a creditor, is a valid and legal offer of payment) in any jurisdiction.

Committee on Payments and Market Infrastructures (CPMI): "digital currency" as any electronic form of money, or medium of exchange that features a distributed ledger and a decentralized payment system.

Bank for International Settlements (2015): “Digital currency is an asset stored in electronic form that can serve essentially the same function as physical currency, namely, facilitating payments transactions.

Central bank digital currency refers to money that meets the following criteria (Grym et al., 2017):

(1) The central bank issues it in digital form.

(2) Anyone has the right to hold it. It is not a privilege reserved to e.g. credit institutions.

(3) It is the same currency as banknotes and central bank deposits. The conversion rate of Bank notes and zero-interest bearing digital cash would always be one-to-one, and at least some economic entities, e.g. banks, could convert it freely into other types of central bank money.

(4) It can be used as a payment instrument in retail payments.

(5) When two parties engage in a transaction, there is no third party - at least not a private one - that verifies or executes the payment as a central counterparty. The same principle applies to banknote payments.

\subsection{The Money Tree}

'A money tree' uses to organize digital currencies into categories. The first category in the money tree distinguishes between physical money and intangible forms of money. The second category in the money tree differentiates between the technologies that digital currencies use to transact. There are two forms of technology currently in use: conventional ledger technology; and DLT and cryptography (Wadsworth, 2018).

a. Conventional ledger technology is a term describing the financial market infrastructure that we currently use to securely transact payments. This infrastructure is centralized and hierarchical, which means only trusted parties can initiate and settle payments to ensure that is not spent more than once and account balances are accurate.

b. DLT and cryptography ensure that crypto-currencies cannot be spent more than once and that account balances are accurate (CPMI, 2017). DLT is a term that describes a ledger that records transactions and account balances, and that is shared over a network of computers.

The third category in the money tree differentiates between digital currencies that are exchanged for cash at a fixed rate (i.e. one-for-one) and those that are 


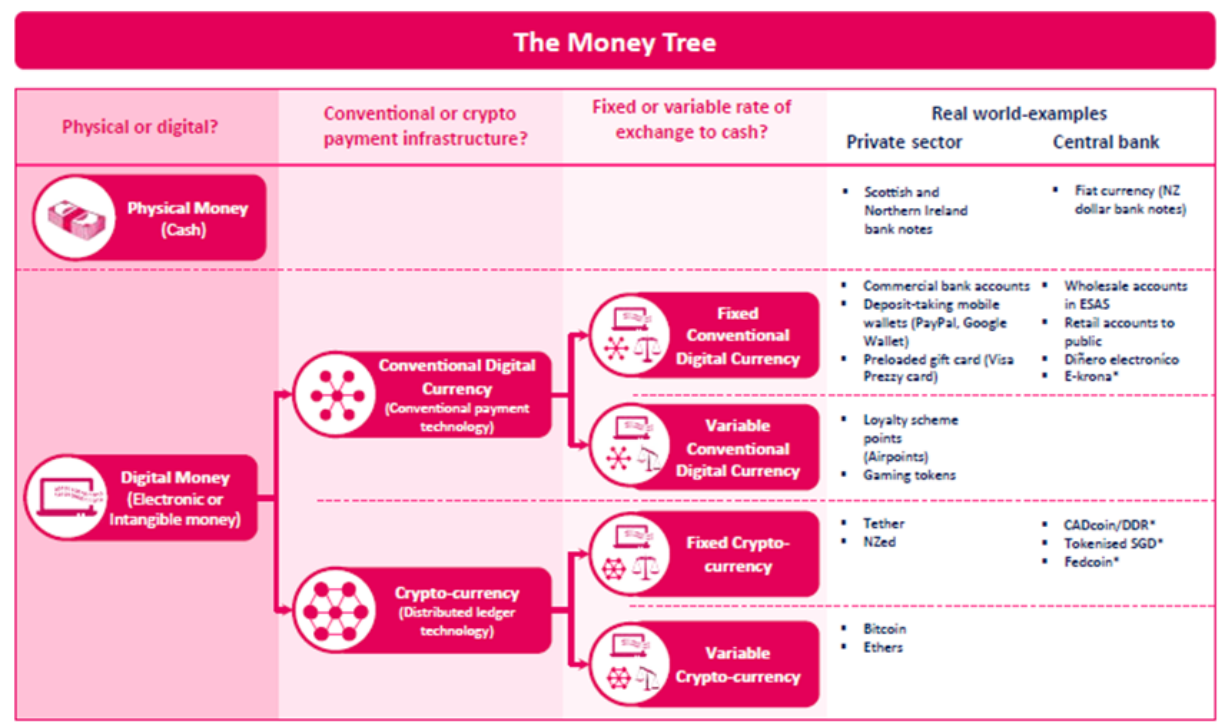

Figure 1: The MoneyTtree Source: Wadsworth (2018)

exchanged at a variable rate.

1) A digital currency with a fixed exchange rate to cash represents a promise for that currency to be redeemed for bank notes and coins at par value at any time. This par value promise then creates an additional source of trust in this form of digital currency.

2) A digital currency with a variable exchange rate to cash is trusted to the extent that people trust the institution that issued it, and the technology that it relies on. This form of currency is more independent from cash.

\subsection{The Money Flower}

It defines a CBDC as an electronic form of central bank money that can be exchanged in a decentralized manner known as peer-to-peer, meaning that transactions occur directly between the payer and the payee without the need for a central intermediary. This distinguishes CBDCs from other existing forms of electronic central bank money, such as reserves, which are exchanged in a centralized fashion across accounts at the central bank.

The money flower distinguishes between two possible forms of CBDC: a widely available, consumer-facing payment instrument targeted at retail transactions; and a restricted-access, digital settlement token for wholesale payment applications. 


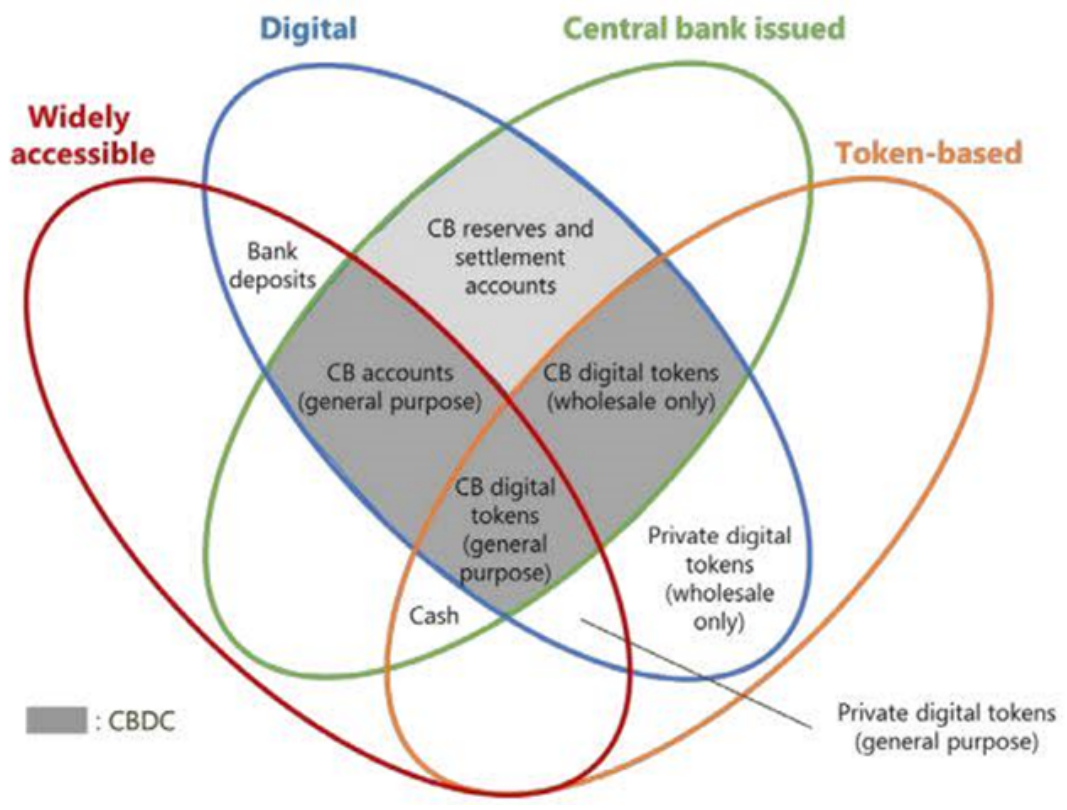

Graph 1: The Money Flower: A Taxonomy of Money

Source: Based on Bech and Garratt (2017)

Notes: The Venn-diagram illustrates the four key properties of money: issuer (central bank or other); form (electronic or physical); accessibility (universal or limited) and technology (account-based or token-based). $\mathrm{CB}=$ central bank, $\mathrm{CBDC}=$ central bank digital currency (excluding digital central bank money already available to monetary counterparties and some non-monetary counterparties). Private digital tokens (general purpose) include crypto-assets and currencies, such as bitcoin and ethereum. Bank deposits are not widely accessible in all jurisdictions. For examples of how other forms of money may fit in the diagram, please refer to the source.

\section{Effect of Central Bank Digital Currency on Monetary Policy}

The stakes of the central bank (Østbye, n.d.):

a. The mandate of the central bank: monetary stability, financial stability, and efficient payment system.

b. Requirements to money: medium of exchange, unit of account, and store of value.

c. Requirements to the payment system: cost-efficient, fast, secure, useful and user-friendly.

The impact may be negative if non-banks replace commercial bank deposits with CBDC to a significant extent. More generally, any materialization of CBDC would have to be assessed against four principles: (1) technological safety, (2) efficiency, (3) technological neutrality, and (4) freedom of choice for users of means of payments. Monetary policy under CBDC is partly very recognizable, 
because the policy interest rate would be used as it is today, and partly unfamiliar, because monetary policy would control a second instrument that determines the manner in which CBDC is issued.

\subsection{Canada}

Central banks typically do not vary bank note supply to implement monetary policy; that is, bank notes are not considered to be a monetary policy tool. Indeed, in many countries, including Canada, bank notes are supplied passively to meet public demand. The benchmark CBDC (which does not pay interest) is supplied in the same way as bank notes, so it would not have material implications for the implementation of monetary policy. More fundamentally, the central bank would remain the ultimate (monopoly) supplier of reserves, bank notes and CBDC, so it could continue to set related terms and conditions of these instruments and therefore control monetary policy (Engert \& Fung, 2017).

Regarding unconventional monetary policy and reducing the ELB on interest rates, it is the elimination of cash, not the introduction of CBDC that is relevant. Indeed, issuing the benchmark CBDC itself would improve agents' ability to store value and escape from negative interest rates, and so would raise the ELB. More specifically, Witmer and Yang (2015) estimate that the ELB in Canada is likely to be around -50 basis points; with the benchmark CBDC, the ELB probably would increase somewhat, toward zero. In addition, the effectiveness of helicopter money might be reduced if a significant fraction of CBDC were held by nonresidents (The benchmark CBDC is anonymous and thus the central bank cannot target such actions toward residents only) (Engert \& Fung, 2017).

The central bank would remain the ultimate (monopoly) supplier of reserves, bank notes and CBDC (interest-bearing or not), so the central bank could set related terms and conditions, and therefore control monetary policy. So, again, paying interest on CBDC should not compromise or fundamentally affect a central bank's ability to influence short-term interest rates to achieve price stability, although implementation tactics could change. In principle, one would expect that the interest rate paid by the central bank on reserves would be the same as the interest rate paid on I-CBDC, as each reflects the setting of monetary policy. These liabilities are also close substitutes in some contexts. Further, a spread between the interest rates on reserves and I-CBDC would provide arbitrage opportunities for clearing banks, which would tend to attenuate any difference between the interest rates on these central bank liabilities, as explained below. (The following abstracts from market frictions and nuances related to floors and ceilings in a corridor-type policy rate system, as in Canada (Engert et al., 2008).

(1) If the overnight rate on reserves was less than the interest rate paid by the central bank on I-CBDC, then clearing banks would borrow reserves from other clearing banks and especially from the central bank and invest the proceeds in I-CBDC to earn the spread. Other things being equal, this would tend to increase the overnight rate on reserves or decrease the yield 
on CBDC until the spread disappeared. To the extent that the central bank lends reserves indefinitely to sustain the overnight rate below the rate paid on ICBDC, then clearing banks could earn the related spread indefinitely.

(2) If the overnight rate on reserves was greater than the interest rate paid by the central bank on I-CBDC, then clearing banks would borrow I-CBDC in the market and invest the proceeds in reserves to earn the spread. Other things equal, this would tend to reduce the overnight rate or increase the market yield on CBDC until the spread disappeared.

As a result of these considerations, it appears that consistency between the interest rate on central bank reserves and the interest rate on I-CBDC should be expected. Thus, the overnight rate (which would be equivalent to the rate on I-CBDC) would determine short-term bank and market interest rates in the first instance, and together with expectations, affect longer-term rates across the yield curve (Engert \& Fung, 2017).

However, such close links between the policy rate and consumer and market interest rates might not hold in a negative interest rate environment, largely because commercial banks could be unwilling to pass on negative rates to all their customers. For example, in Sweden and Switzerland, while the policy interest rate has been negative for some time, commercial bank deposit rates have remained above zero (Engert \& Fung, 2017).

However, when a central bank reduces the interest rate on I-CBDC, especially as part of an effort to generate negative interest rates, the central bank could be seen as (more) directly impairing the welfare of those who rely on interest income from a safe investment, including those members of society who might be less financially sophisticated and have few financial alternatives (Engert \& Fung, 2017).

Another possible concern for central banks arising from declining bank notes is a threat to their core revenue stream-seigniorage. Central bank seigniorage is a function of the value of bank notes outstanding (multiplied by the prevailing interest rate, less costs of note production and distribution.) Therefore, seigniorage would decline as value of bank notes falls, and seigniorage would be especially affected if higher-denomination notes declined since they generate more revenue than smaller-value notes. The issue here is that if seigniorage declines significantly, a central bank might need to rely on government funding, and this could ultimately undermine its autonomy (Engert \& Fung, 2017).

In most economies, however, notwithstanding the declining relative importance of bank notes, the value of bank notes outstanding-in absolute terms and relative to gross domestic product (GDP) is not declining (Mersch, 2017b). Moreover, the distribution of notes in Canada has been shifting toward higher denominations, which generates more seigniorage, other things being equal. As a result, and despite historically low interest rates in recent years, the amount of central bank seigniorage in Canada has varied between US $\$ 1$ and US $\$ 2$ billion per year over the past two decades.

Accordingly, seigniorage in Canada has not been at risk. Similar propositions 
hold in most other countries, with the exception of Sweden and Norway. And it seems unlikely that this secular pattern in Canada will materially change in coming years (Fung et al., 2015). Zurbrügg (2017) provides a similar perspective for Switzerland. But even if the demand for bank notes were to decline significantly, leading to a decrease in bank notes outstanding and thus threaten seigniorage, issuance of CBDC is not the only possible response, as there are other ways for a central bank to sustain its revenues (Fung et al., 2014).

In sum, preserving seigniorage does not provide a compelling motivation to issue CBDC in Canada (or in most other advanced economies), based on recent trends. More generally, however, further research could consider whether a sound financial system requires a central bank liability (which is both liquid and risk-free) accessible to the general public, like bank notes or CBDC. Related to this, there might be a concern that if private cryptocurrencies became widely adopted and displaced central bank money, there could be adverse implications for central bank monetary policy and for financial stability. Currently, this prospect does not appear to be a pressing matter. For example, Bitcoin adoption and holdings appear to be low in Canada and in the United States, although adoption could accelerate over time (Henry et al., forthcoming). Looking ahead, therefore, ongoing monitoring and research regarding these issues would be prudent (Engert \& Fung, 2017).

Some of the motivations for CBDC considered here are not compelling, including reduction of the ELB on interest rates, and inhibiting criminal activity. Promoting financial inclusion could be an important consideration in some countries, perhaps especially emerging economies, but does not provide a motivation in the Canadian case. Based on current trends, there does not appear to be a meaningful concern in most countries considered here about preserving seigniorage or maintaining adequate central bank money for the general public. As noted, the role or need for such central bank money more generally is a topic for future research. However, improving financial stability (section 2.3) might provide a motivation for the issuance of CBDC, and increasing contestability in payments (section 2.4) seems most likely to provide a sound motivation to issue CBDC. A more complete assessment of these motivations depends on the specific nature of the CBDC, which is considered in the following sections.

The effects of CBDC on monetary policy, the financial system and the wider economy could be significant; see, for example, Barrdear and Kumhof (2016), Mersch (2017a), Sams (2015), and Koning (2014). But the nature and extent of such consequences probably depend on the specific features of the CBDC (Fung \& Halaburda, 2016). Further, different CBDC designs-that is, different bundles of attributes-would generate different trade-offs along several dimensions. There is also uncertainty about the potential consequences, given the inherent complexity of the design issues, and the pervasiveness of possible effects. In other words, the effects of CBDC depend on the attributes of CBDC and are difficult to predict, and the significance of effects and uncertainty increase with the extent of innovation (Engert \& Fung, 2017). 
Features of the benchmark CBDC: Like cash. Given the preceding considerations, the benchmark CBDC in this paper is designed to conform as much as possible to a familiar environment and mimic bank notes. This conservative approach is more likely to avoid significant errors and lead to reliable analysis. Put differently, the benchmark CBDC here is designed to minimize disruption by having properties similar to its physical analogue, cash. Also, the benchmark CBDC complements-and does not replace-cash.

Assumed that the central bank has access to the technology that would allow the issuance of a CBDC with this list of features (Engert \& Fung, 2017).

Denomination: The benchmark CBDC is denominated in the sovereign currency; for Canada, the Canadian dollar.

Legal tender: Like cash, the benchmark CBDC is legal tender.

Convertibility: The central bank would exchange reserves, bank notes and CBDC at par with financial institutions that have an account at the central bank, just as reserves and bank notes are exchanged at par today. This would lead to par exchange of bank notes and CBDC among the general public.

Non-interest-bearing: Like cash, the benchmark CBDC does not bear interest.

Central bankfees

1) The central bank does not charge fees for distributing/exchanging or storing CBDC, or for making payments using CBDC.

2) Commercial banks could, however, decide to charge fees for services related to CBDC.

Access to $C B D C$

1) Access is non-exclusive-anyone could use the CBDC-but access to related technology is required.

2) CBDC is held and transferred with a chip card or a digital wallet available to any person or firm with the technology, through various devices, including personal computers, tablets and mobile phones with online capability.

3) The digital wallet would be provided by designated private service providers that are certified or licensed by the central bank.

4) As noted above, the underlying technology (like a digital ledger) is not specified here.

Availability of CBDC: The benchmark CBDC would be available 24/7, like cash and other electronic payment methods.

Confidentiality of $C B D C$ use

1) The benchmark CBDC is anonymous or pseudonymous, depending on the technology used. As a result, transactions using CBDC would be impossible to trace.

2) The CBDC is subject to the risk of theft and loss, including through technological impairment. The latter could occur, for example if CBDC were stored on a hard drive that was reformatted or destroyed, or if a user lost the password/private key.

3) Transactions are non-reversible, unless both transacting parties agree and engage in a reversing transaction. 
Supply by central bank

1) The central bank supplies as much digital currency as the public is willing to hold.

2) As a result, supply is demand-determined and perfectly elastic.

Distribution channel used by central bank

1) Similar to current bank note distribution in Canada, households and firms would purchase the benchmark CBDC at a regulated financial institution (e.g., a bank) with their deposits at those institutions or with bank notes. Bank customers could also withdraw CBDC from their bank accounts, which is conceptually similar to the withdrawal of cash.

2) These regulated financial institutions would have accounts at the central bank or have accounts at clearing banks that have accounts at the central bank, where they could purchase the benchmark CBDC for customers directly or indirectly with their deposits or bank notes.

3) Banks would have to comply with know-your-customer (KYC) and antimoney laundering (AML)/combating the financing of terrorists (CFT) requirements for their CBDC operations, similar to bank notes today. However, once the benchmark CBDC is withdrawn from a bank, it would be anonymous to the issuer and the counterparty in a transaction.

4) There would be no direct access to the central bank for households and firms to obtain, store or return the benchmark CBDC.

Finality and irrevocability

1) To be used for payments, benchmark CBDC transactions need to be confirmed nearly instantaneously, and the underlying transactions need to be settled irrevocably as quickly as possible.

2) The timing of finality and irrevocability of benchmark CBDC transactions depends on the technological solution underpinning the CBDC.

CBDC payment network structure

1) The payment network for the benchmark CBDC is distributed and bilateral, and not tiered. The specific features and feasibility of these elements depend on the design of the digital wallet and ledger.

2) A digital currency is closely affiliated with its network-the means by which authenticity and validity of the currency are maintained and the risk of counterfeiting is managed in a digital context (e.g., a distributed ledger). That is, a digital currency cannot exist independently of a network. Therefore, the validity and usefulness of a CBDC would be intricately connected to the digital wallet in which it is stored and the network over which it is transferred.

3) As noted above, the focus here is on the economics of CBDC, so these technological considerations, including associated costs and risks to the central bank, are not considered further in this paper.

CBDC payment network structure

1) The payment network for the benchmark CBDC is distributed and bilateral, and not tiered. The specific features and feasibility of these elements depend 
on the design of the digital wallet and ledger.

2) A digital currency is closely affiliated with its network-the means by which authenticity and validity of the currency are maintained and the risk of counterfeiting is managed in a digital context (e.g., a distributed ledger). That is, a digital currency cannot exist independently of a network. Therefore, the validity and usefulness of a CBDC would be intricately connected to the digital wallet in which it is stored and the network over which it is transferred.

3) As noted above, the focus here is on the economics of CBDC, so these technological considerations, including associated costs and risks to the central bank, are not considered further in this paper.

\subsection{Finland}

The new money or payment instrument to be launched does not automatically become popular. Private entities have tried to issue electronic money (Grym et al., 2017). For example, in Finland a chip-based Avant money card was launched in the 1990s. Customers could load e-money onto the card, and it was accepted as a form of payment in telephone booths and some vending machines and shops. The Avant card was a scheme run by Toimiraha $\mathrm{Oy}$, a company initially owned by the Bank of Finland. The company was sold to commercial banks and renamed Automatia Rahakortit Oy. The value loaded on the card was legally electronic money, and it was based on commercial bank money. The popularity of this payment instrument remained low, and the number of users was not large enough to achieve critical mass (Jyrkönen \& Paunonen, 2003). A key factor restricting its popularity was the fact that customers were charged a fee for loading and unloading money, and this did not please consumers and retailers who were accustomed to free-of-charge cash withdrawals at ATMs. Similar chipbased electronic wallets have failed also in other countries, for example Canada (Plouffe et al., 2000). Of the euro area countries, only in the Netherlands a prepaid wallet is still widely used. In addition, the products provided by international card companies created a payment environment of developing and expanding features (speed, ease of use, safety, extensive acquirer network) against which local e-wallets could not compete.

Technically, it would be possible to extend the functionality of ATMs and online banks to handle digital money. The new form of money would offer an alternative to bank deposits, and therefore the stock of low interest-bearing deposits by private customers as a source of bank funding could become more unstable. At the end of 2016, the deposits of Finnish households totaled over EUR 85 billion, and the average interest rate on these deposits was below 0.2 percent (Grym et al., 2017). If the new form of money was to widely replace deposits on household and corporate balance sheets, banks could offer higher interest rates on accounts or additional services to attract deposits back. Alternatively, banks would have to resort to more large-scale borrowing from somewhere else. 
If deposits of the public were to flow to the central bank balance sheet in the form of digital money, this would result in a financial surplus for the central bank and, correspondingly, commercial banks would be faced with a financial deficit. In such a case, the central bank would need to increase its financing to commercial banks. Since central banks provide liquidity against collateral, commercial banks would need more securities as collateral. This could increase e.g. securitization of bank loans.

Another potential problem could be the impact of CBDC on the risk of bank runs. Digital money and bank deposits would likely be closer substitutes than banknotes and deposits (Riksbank, 2017). Therefore, bank customers might switch from deposits to central bank money for more minor reasons than before. In principle, bank runs could also occur at times when bank offices are closed. The higher risk of bank runs should be taken into account e.g. in bank liquidity regulations: retail deposits would no longer be as reliable and stable a form of funding as has customarily been the case. On the other hand, it must be noted that modern deposit guarantee scheme have effectively prevented bank runs (Grym et al., 2017).

It is extremely difficult to estimate the macroeconomic implications of digital money without historical experience. Similar types of payment instruments developed by the private sector are not very common, implying that we have no experience to assess the macroeconomic or other broader effects. Therefore, no actual conclusions can yet be drawn. However, we can propose some hypotheses, the realization of which must be monitored, should CBDC someday be issued somewhere in the world (Grym et al., 2017).

If digital cash were to compete with traditional cash, customers' marginal propensity to consume could increase slightly. Studies in behavioral economics have shown that consumers spend less when they use traditional money as opposed to account money (Mercatanti \& Li, 2014). Digital money would be as abstract as a bank account balance, and therefore it could have similar psychological effects. Easy access to credit blurs budget constraints and increases the risk of payment defaults. Of course, digital money would be determined as money without the possibility for credit, in which case the central bank would not need to worry about the credit risk.

CBDC could also increase dollarization, i.e. situations in which residents widely use some foreign currency other than their national legal tender. As a rule, an economy does not gain from dollarization. Instead, dollarization amplifies cyclical fluctuations and reins in economic growth (Yeyati, 2006). Financial dollarization typically results from high inflation or other factors which have undermined the credibility of the domestic currency, while legal barriers to the use of foreign currency reduce dollarization. If a form of central bank money exists that can be transmitted across borders at a low cost and stored in digital format, it is easier for private sector actors to start using some currency other than their own national legal tender. Nobody would have to carry cash from one country to another, and the absence of currency supply, for example, would not 
pose a problem. In many cases, using and holding currency would be equally easy, irrespective of one's place of residence. A lesser loss of confidence in legal tender could lead to a partial or complete abandonment of the domestic currency (Grym et al., 2017).

Because of network effects, everyone should primarily use the currency that is most common in their own operating environment. One of the natural environments to use CBDC is the Internet. The Internet has no geographical position, and money circulating on the Internet has no natural currency areas in the traditional geographical sense. Dollarization may begin in online shopping and spread later from the Internet to other activities. If residents of a country make a considerable share of their transactions online, and in foreign currency, they may be more willing to use the same currency also in other situations to avoid the use of two parallel currencies. This could pose a problem particularly for small currency areas and emerging economies.

\subsection{Sweden}

The effects on the balance sheet mean that the introduction of an e-krona could have different types of consequences for monetary policy. The e-krona could affect both the implementation of monetary policy as well as the transmission mechanism and policy framework. How large these consequences might be depends on how the e-krona system is designed (Riksbank, 2017).

Implementation of monetary policy (Riksbank, 2017). A concrete consequence for monetary policy is that the Riksbank would need to forecast how much e-krona is expected the following week in order to be able to plan its market operations. If the banks have invested all the structural surplus in Riksbank certificates and the demand for e-krona suddenly increases, the banking system will "tip over" to a deficit with the Riksbank. The banks would then be forced to borrow overnight in the Riksbank's fine-tuning or sell back some of their certificates to cover their liquidity deficit. In order to stabilize the overnight rate close to the repo rate, the Riksbank needs to be able to cope with changes in factors that are beyond its own control, such as the general public's demand for banknotes and coins as well as for e-krona.

It is possible that it might be more difficult to forecast the amount of e-kronas than the amount of cash, as digital e-kronas can be expected to be more volatile because of its real-time properties. This is a question that the Riksbank will look at in more detail.

The transmission mechanism and the monetary policy framework (Riksbank, 2017). How the pricing of an e-krona is calibrated and how access to the e-krona is controlled, will be the decisive factor as regards demand for e-kronas. If the e-krona is designed as an interest-free means of payment like banknotes and coins that the Riksbank provides to the extent demanded by the general public, the e-krona will be another factor outside the monetary policy implementation framework, a so-called "autonomous factor", which the Riksbank cannot control 
but nevertheless needs to consider when implementing monetary policy (see Figure 2 below). If, on the other hand, the e-krona accrues interest, it will be an instrument that needs to be incorporated into the monetary policy implementation framework. Moreover, if the general public has access to e-kronas by having accounts directly at the Riksbank, current monetary policy counterparties (the banking system) will no longer be the only agents that the Riksbank needs to consider.

The Riksbank'sliability side

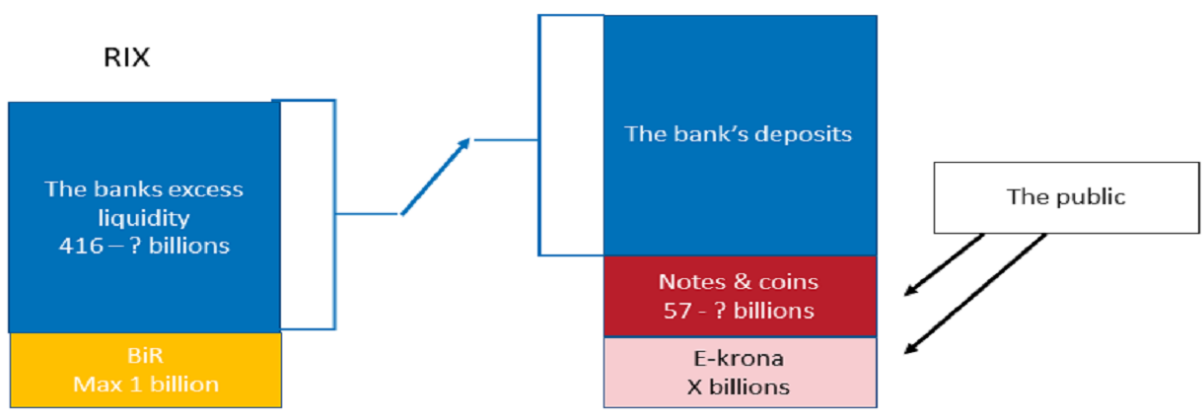

Figure 2: E-kronas Constitute Another Autonomous Factor In The Implementation Of Monetary Policy

Source: Riksbank (2017)

A central bank's task is to have a well-balanced framework for the implementation of monetary policy and adjustments to international changes are made when necessary. The Riksbank should regularly analyze and forecast the amount of e-kronas in circulation. One question that is usually raised in connection with digital currencies is concern over a bank run, whereby the general public would move money from their bank accounts to the central bank accounts and the difficulty in forecasting the banks' liquidity positions in relation to the central bank. For instance, if there were to be a severe bank run, the Riksbank's current terms and conditions regarding collateral would limit how much lending the Riksbank could offer to the banks, as the sums would easily exceed the collateral the participants have available. These questions need to be investigated further, but an initial assessment is that they are not serious obstacles to an e-krona. The Riksbank currently issues banknotes and coins in the volume demanded by the general public and the same should apply to an e-krona (Riksbank, 2017).

Another important issue for monetary policy which will become relevant if an e-krona is introduced is where the lower bound for the Riksbank's policy rate will be, i.e. at what level do cuts to the policy rate stop having an effect on real interest rates. If banks offer loans and investments at negative rates, the borrower, who has borrowed money at a negative rate, can make a profit by withdrawing the money in cash as the yield on interest-free cash is zero percent (Riksbank, 
2017).

In practice, there are a number of costs associated with managing cash, which effectively means that the yield from cash in not zero but actually negative. The interest rate level at which the general public becomes indifferent towards having money in an account at a negative rate and holding cash will be under zero percent and therefore the lower bound for the policy rate will not be exactly zero, but slightly below. In this situation, it may be worth considering how an e-krona might affect the lower bound. If an e-krona does not accrue any interest, it may be more difficult to determine where the lower bound for the policy rate runs as management costs for an e-krona can be assumed to be lower than for cash. An e-krona that does not accrue interest could in other words mean that the lower bound is adjusted upwards, closer to zero, while an e-krona with a negative interest rate would retain the possibility of a negative policy rate (Riksbank, 2017).

A digital central bank currency, here called an e-krona, has the following basic characteristics (Riksbank, 2017):

(1) It is specified in the national value unit, the Swedish krona.

(2) It constitutes a claim on the central bank (the Riksbank).

(3) It is electronically available 24 hours a day, 7 days a week, 365 days a year and available in real time or close to real time.

(4) It is available to the general public, i.e. is more broadly available than traditional central bank deposits in RIX, to which only the banks have access.

E-krona would be partly or wholly able to manage some of the potential problems identified on a future payment market (Riksbank, 2017).

(1) An e-krona is a digital means of payment, unlike cash, which is physical. Those people who wish to use cash will probably continue to prefer cash over a digital e-krona in the future. Otherwise, it is difficult, at present, to assess how an e-krona could affect cash usage.

(2) The e-krona's digital nature makes it less likely that it could contribute towards mitigating the problems that certain groups of consumers and companies experience as cash usage declines. On the other hand, under the framework of the e-krona, the Riksbank could create the conditions for other participants to develop payment services adapted to particular groups in society or even fund such a development, to a certain extent.

(3) If the e-krona offers a technical infrastructure that can function independently of the commercial, bank-owned infrastructure, then it could contribute to the payment systems becoming more robust, both against technological disruptions and in situations of financial unease. This is in line with the Riksbank's mandate to promote a safe payment system.

(4) An e-krona with its own settlement platform, accessible to payment service providers, could become a platform for new, innovative payment services.29 This is in line with the Riksbank's mandate to promote an efficient payment system. 
(5) An e-krona would safeguard the general public's access to central bank money, which is to say an asset without financial risk. This is in line with the Riksbank's task of promoting confidence in the Swedish krona.

An e-krona intended to be used for smaller payments between consumers and between consumers and companies could take market shares from other digital payment services and thereby grow to a certain size. It could thereby counteract the problems inherent in the increased consolidation of the payment market, which the other measures cannot. The size of the market share that an e-krona could take depends on what form it takes. An e-krona would also guarantee the general public continued access to central bank money (Riksbank, 2017).

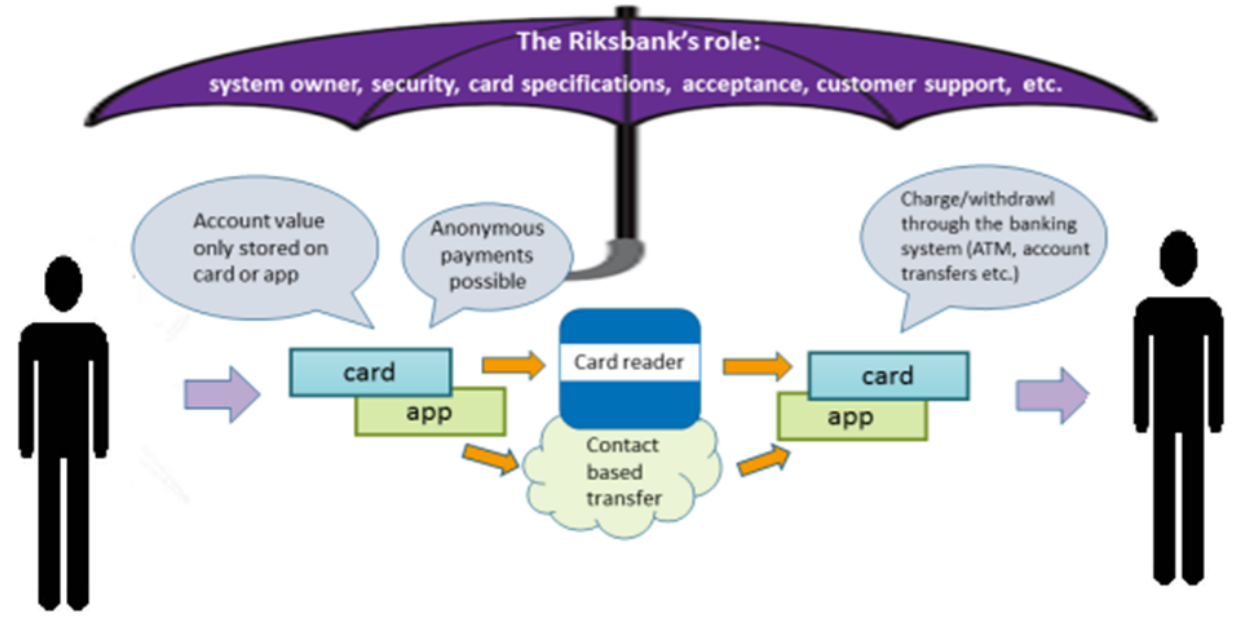

Figure 3: A Value-based E-krona Source: Riksbank (2017)

Irrespective of the degree of involvement, services for the general public imply a considerable commitment and responsibility as regards (Riksbank, 2017):

(1) System development and administration,

(2) Regulatory framework and agreements with sub-contractors/partners,

(3) Issue/account holding of e-kronas,

(4) Customer due diligence, money laundering prevention, customer service

(5) Transaction authorization,

(6) System security in the form of IT security, operational reliability and information security as well as protection against cybercrime and fraud,

(7) Interoperability with technical infrastructure and other digital solutions abroad existing and future,

There are certain technical properties that an e-krona should have regardless of how it is designed. These are listed below (Riksbank, 2017).

(1) Scalability: An e-krona must have a solid base, which can gradually be 
extended in different stages, as the requirements for the e-krona solution are developed and needs and external conditions change. The base solution should therefore be constructed so that it can be integrated with new modules and functions via open, standardized interfaces. The aim should be that the technical solution is sustainable in the long run and that it can be developed by the Riksbank and/or other parties. In this way, the Riksbank's operative role will be more flexible. It is also desirable that technical innovations can be incorporated and utilized in a quality-assured way as such innovations become available. For example, Distributed Ledger Technology (DLT)39 could be utilized when and if the technology is considered appropriate. An e-krona platform should be constructed so that different technologies can interact as much as possible.

(2) Interoperability: An e-krona solution should be portable as far as possible and function equally well regardless of the type of unit and operative system used. It should be possible to adapt the e-krona to future technical innovations. For this to work, the e-krona must be based on generally accepted standards and frameworks enabling it to work together with other digital solutions and technical infrastructures.

(3) Reliability: The e-krona solution must be robustly built so that it guarantees good operational reliability and can have the best available protection against cyber-attacks and different types of fraud. Another aspect linked to the concept of reliability is the issue of anonymity and integrity regarding traceability. The degree of anonymity that shall or shall not be offered by an e-krona can influence the choice of technology. The anonymity offered by today's physical cash may be difficult, and perhaps not even desirable, to recreate in a digital e-krona. There are legal requirements regarding the traceability of transactions that must be fulfilled.

(4) Accessibility: The technical solution for an e-krona must be designed so that it is easy and intuitive to use and offers good performance, for instance, with regard to transaction speed. It is also important that the solution offers functions adapted to different target groups. It should be accessible 24 hours a day, seven days a week, 365 days a year.

\subsection{Spain}

CBDC is typically conceived as a deposit at the central bank available to households and firms. Consequently, CBDC shares characteristics with banknotes and bank reserves. Regarding anonymity and remuneration, various possibilities are envisaged, which will be discussed below. This system may or may not be anonymous (as in the respective cases of banknotes and bank reserves). Likewise, CBDC may or may not be remunerated (Nuño, 2018).

CBDC also shares characteristics with private digital money, represented by accounting entries in agents' current accounts, which can be mobilized without the need for the use of banknotes, for instance through bank transfers or debit 
Table 2: Comparison between Reserves, Banknotes, and CBDC

\begin{tabular}{llll}
\hline & Reserves & Banknotes & CBDC \\
\hline Format & Digital & Physical & Digital \\
Access & Restricted & Universal & Universal \\
Anonymity & Non-anonymous & Anonymous & Both possible \\
Remunerated & Yes & No & Both possible \\
\hline \multicolumn{2}{l}{ Source: Banco de España (Nuño, 2018) }
\end{tabular}

cards. The main difference is that CBDC is a public digital currency, issued by the central bank (Nuño, 2018).

The recent literature has indicated three main reasons why some central banks might consider the future introduction of CBDC (Bech and Garratt, 2017): (i) the lesser demand for cash in some jurisdictions; (ii) possible improvements in some aspects of the workings of the payment system, and (iii) potential improvements in monetary policy transmission. Moreover, in many of the countries in which the introduction of the CBDC is being considered, regard is also had to other more general aspects of economic policy, such as combating tax fraud and moneylaundering, and financial inclusion. Each of these reasons are analyzed below in greater detail.

One reason for issuing CBDC might be the impact that a potential replacement of cash with digital means of payment might have on seigniorage, i.e. the profit the central bank obtains on the issuance of banknotes, whose production cost is small compared with their face value. Secondly, some studies conclude that the introduction of CBDC might improve certain aspects of the functioning of payment systems. Recent analyses estimate considerable gains in productivity associated with the introduction of CBDC (see Barrdear and Kumhof, 2016). The third reason is the potential improvement in monetary policy transmission (see Haldane, 2015; Rogoff, 2017; Bordo \& Levin, 2017a or Meaning et al., 2018). Firstly, if CBDC were remunerated, its interest rate would become a key instrument for implementing conventional monetary policy, since it would affect household and corporate saving and investment decisions, either directly (through the remuneration of funds deposited at the central bank) or indirectly (by setting a lower bound on the remuneration of bank deposits). That would enable monetary policy transmission to be decoupled in part from banks' financial situation, which might prove particularly important during financial crises.

Other study, the CBDC might be conducive to other economic policy goals, such as combating financial exclusion and tax fraud (He et al., 2017). In the case of the fight against tax fraud and money-laundering, it should be highlighted that the CBDC can play a significant role provided that holdings thereof are not anonymous, i.e. when the central bank maintains an active register of all transactions in the economy. Nonetheless, the attainment of such an objective would further require that the use of cash be eliminated so as to prevent it from being the vehicle used for illegal activities (Nuño, 2018).

Remunerated CBDC would be something more of a novelty. Confining our- 
selves to the case where such remuneration were never higher than that on bank reserves, the latter would continue to be the floor for short-term interbank yields. However, given that the CBDC is an alternative to current accounts as a store of value and a means of payment, the remuneration thereon would indeed be an effective floor for the rates at which the different economic agents with access to CBDC lent funds to banks. For example, giving access to CBDC to non-bank financial institutions would set an effective floor to broadly defined money market rates. Likewise, the remuneration on CBDC would establish a lower bound for the interest rates on households' and firms' deposits. Thus, changes in the CBDC rate would affect agents' spending and saving decisions, either directly through the remuneration of funds deposited at the central bank, or indirectly through their effect on the remuneration of deposits at commercial banks. In turn, changes in banks' funding costs have a bearing on the interest rates at which banks lend to the real economy. In short, the remunerated CBDC scenario would afford the central bank greater control over the general financial conditions in the economy and, therefore, over aggregate demand.

CBDC is that related to the improvement in monetary policy conduct by means of a better control of the market returns that savers and borrowers face. Also, the possibility of eliminating the restrictions associated with the zerointerest-rate bound is theoretically attractive, especially in an environment of low interest rates as at present (Galesi et al., 2017). However, the attendant uncertainties and risks are significant and oblige central banks to be cautious in this respect.

\subsection{Ecuador}

Ecuador is one of the countries that started to implement an electronic money system in 2015, whereby the Central Bank of Ecuador (CBE) exclusively manages e-money in the country and, as such, allows any citizen to hold an e-money account at the CBE (Ketterer \& Andrade, 2016). The feasibility of CBDC has been demonstrated in Ecuador, where CBDC has become widely available through a simple and secure platform (i.e., two-step verification with cellphones and text messages) (Bordo \& Levin, 2017b).

Central bank of Ecuador issued digital currency, named dinero electronico. It's used for:

(1) Payment tool (tool of payment),

(2) Encourage the development of financial inclusion,

(3) Increase acceleration of money circulation through new payment methods,

(4) Do not replace the US dollar as a legal tender in Ecuador.

Issuance steps of dinero electronico:

(1) First, December 2014, users have access to open an account at BCE,

(2) Second, February 2015, transactions have been made (transactions loading, unloading, sending e-money between users, and bank transfers),

(3) Third, In the second semester of 2015, electronic payments from corpora- 
tions that serve public services, tax obligations, drafts, and others could be done.

Dinero electronico implication to financial inclusion:

(1) Increase the efficiency of transaction costs,

(2) Reducing barriers to access to the financial system,

(3) Give people access to financial services and credit,

(4) Increase the use of financial services through mobile phones,

(5) Accommodate financial inclusion digitally,

(6) New and ideal payment tool for small companies.

Benefits of dinero electronico issunce:

(1) Strengthen dollarization by cutting paper money applications,

(2) Saves key costs, storage and distribution of banknotes of US\$12 billion/year,

(3) Increase financial inclusion,

(4) Low interest hosting,

(5) Improve interoperability,

(6) Expand the small business expansion network.

\subsection{Indonesia}

Bank Indonesia as central bank of Indonesia making research about the possibility of issuing a digital rupiah currency (Central Bank Digital Currency). The CBDC is the digital form of fiat money; in this case, the digital version of the Indonesian rupiah. Therefore, it is different from the so-called digital currency (also known as virtual currency or cryptocurrency) which are not issued by the state and therefore lack the legal tender status declared by the government.

Through Bank Indonesia Regulation No. 18/40/PBI/2016 on the Implementation of Payment Transaction Processing as well as Bank Indonesia Regulation No. 19/12/PBI/2017 on the Implementation of Financial Technology, the central bank of Indonesia bans the use of virtual currencies (such as Bitcoin, Ethereum, Dash, Litecoin, and Ripple) as payment instruments in Indonesia. These virtual currencies are banned as there is no underlying asset or responsible authority/administrator, hence these currencies are more volatile, risky and speculative. This can trigger financial system instability, while there is also concern that digital currencies open room for money laundering or the funding of terrorist activities. Lastly, Bank Indonesia stated that virtual currencies undermine the sovereignty of the Indonesian rupiah within the territory of Indonesia.

For the central bank the advantages of a digital rupiah include lower operational and transaction costs, especially in the remote areas where the distribution of physical money is burdened by infrastructure troubles. A virtual rupiah, on the other hand, can be stored on smartphones, cards, or e-wallets and therefore have a much higher degree of efficiency.

The benefits of CBDC for central bank:

(1) Monetary policy; providing new monetary instrument and improving financial inclusion, 
(2) Financial stability system; improving competition and innovation system, higher financial security system,

(3) Payment system; cost-efficient, secure and innovation payment system.

Bank Indonesia has two alternatives for issuing CBDC. First: Issued by Bank Indonesia, distributed directly to the people, people account directly managed by Bank Indonesia through government to consumer (G2C) method, i.e. dinero electronico in Ecuador. Second: Issued by Bank Indonesia through financial institutions (bank or non-bank), people account managed by out of Bank Indonesia through government to business (G2B) method.

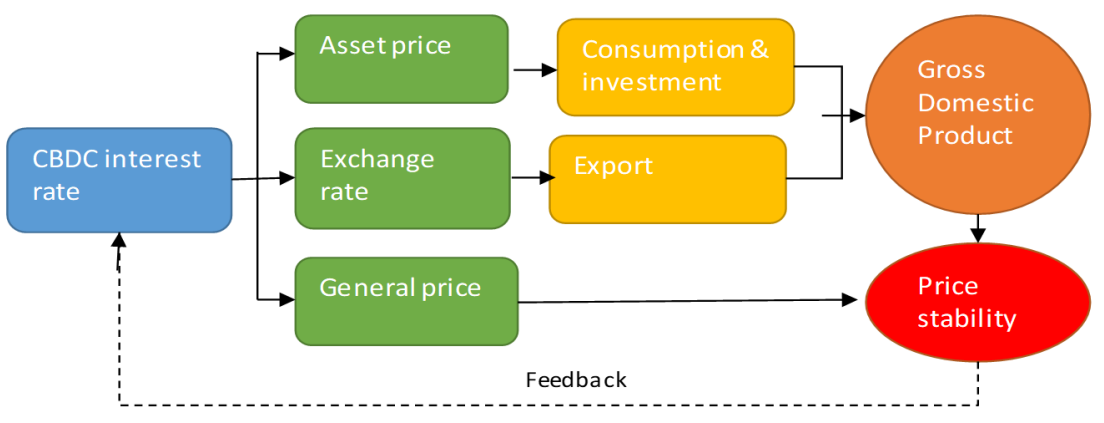

Figure 4: Monetary policy transmission after CBDC

Source: Dewati \& Dewi (2017)

Bank Indonesia, by issuance of CBDC:

(1) The ultimate goal of monetary policy is no longer to achieve a low and stable inflation rate, but to achieve price stability,

(2) Transmission of monetary policy will change from the existing one.

\section{Conclusions}

Central Bank Digital Currency (CBDC) is defined as:

(1) digital currency equivalent to applicable banknotes and coins,

(2) issued and guaranteed by the central bank,

(3) The CBDC denomination is the same as the denomination of the country's currency.

Central Bank Digital Currency (CBDC) functions as:

(1) a stable unit of account,

(2) a medium of exchange or a low-cost payment instrument,

(3) safe value store,

(4) applies as a legal tender.

CBDC can change all aspects of the monetary system and facilitate the implementation of a systematic and transparent monetary policy 
(1) CBDC access is non-exclusive-anyone could use the CBDC - but access to related technology is required,

(2) CBDC has interest rate bearing,

(3) Adjusting the CBDC interest rate according to economic needs can encourage real price stability.

CBDC encourage true price stability, that is the value of CBDC will be stable over time in relation to the consumer price index with a wide range,

(1) The monetary policy framework will facilitate the implementation of a systematic and transparent monetary policy,

(2) The use of CBDC provides a new monetary instrument that allows the central bank to reduce interest rates below zero (zero lower bound).

The issuance of CBDC will change the objective of Bank Indonesia from the initial achievement of rupiah value stability, to achieve stability in the prices of goods and services in the real sector (price stability).

(1) Issuance of CBDC which is subject to interest (interest bearing) will allow monetary policy to focus on the stability of price levels rather than inflation rates,

(2) This change will change the transmission path of monetary policy.

\section{References}

[1] Bank for International Settlements (BIS). (1996). Implications for central banks of the development of electronic money. https://www.bis.org/publ/bisp01.htm.

[2] Baron, J., O'Mahony, A., Manheim, D., \& Dion-Schwarz, C. (2015). National security implications of virtual currency: Examining the potential for non-state actor deployment. RAND Corporation-NDRI Santa Monica United States. https://www.rand.org/ pubs/research_reports/RR1231.html.

[3] Barrdear, J., \& Kumhof, M. (2016). The macroeconomics of central bank issued digital currencies. Staff Working Paper 605. Bank of England. https://www.bankofengland.co.uk/working-paper/2016/ the-macroeconomics-of-central-bank-issued-digital-currencies.

[4] Bech, M. L., \& Garratt, R. (2017, September). Central bank cryptocurrencies. BIS Quarterly Review, 55-70. https://www.bis.org/publ/qtrpdf/r_qt1709f.htm.

[5] Bhaskar, V. (1998). Informational constraints and the overlapping generations model: Folk and anti-folk theorems. The Review of Economic Studies, 65(1), 135-149. doi: https://doi.org/10.1111/1467-937X.00038.

[6] Bhaskar, V., Mailath, G. J., \& Morris, S. (2012). A foundation for Markov equilibria in sequential games with finite social memory. The Review of Economic Studies, 80(3), 925-948. doi: https://doi.org/10.1093/restud/rds047.

[7] Bordo, M. D., \& Levin, A. T. (2017a). Central bank digital currency and the future of monetary policy. NBER Working Paper No. 23711. National Bureau of Economic Research. doi: 10.3386/w23711.

[8] Bordo, M. D., \& Levin, A. T. (2017b). Central bank digital currency and the future of monetary policy. Hoover Institution Economics Working Papers No. 17104. Stanford University. https:/ /www.hoover.org/sites/default/files/research/docs/ 17104-bordo-levin_updated.pdf. 
[9] Carstens, A. (2018, February 6). Money in the digital age: what role for central banks?. Lecture at the House of Finance, Goethe University, Frankfurt. https:/ /www.bis.org/ speeches/sp180206.htm.

[10] Chwe, M. S. Y. (1999). The reeded edge and the Phillips curve: Money neutrality, common knowledge, and subjective beliefs. Journal of Economic Theory, 87(1), 49-71. doi: https://doi.org/10.1006/jeth.1999.2533.

[11] CPMI. (2003). The role of central bank money in payment systems. CPMI Papers No 55. Committee on Payments and Market Infrastructures - Bank for International Settlements. https://www.bis.org/cpmi/publ/d55.htm.

[12] CPMI. (2017). Distributed ledger technology in payment, clearing and settlement: An analytical framework. CPMI Papers No 157. Committee on Payments and Market Infrastructures - Bank for International Settlements. https://www.bis.org/cpmi/ publ/d157.htm.

[13] Dewati, W., \& Dewi, K. (2017). Central Bank Digital Currency (CBDC) dan pengaruhnya terhadap tujuan dan tugas Bank Indonesia [PowerPoint slides]. BI Presentation Paper, not published. Bank Indonesia .

[14] Engert, W., \& Fung, B. S. (2017). Central bank digital currency: Motivations and implications. Bank of Canada Staff Discussion Paper 2017-16. Bank of Canada. https: //www.bankofcanada.ca/2017/11/staff-discussion-paper-2017-16/.

[15] Engert, W., Gravelle, T., \& Howard, D. (2008). The implementation of monetary policy in canada. Bank of Canada Discussion Paper 2008-9. Bank of Canada. https: //www.bankofcanada.ca/2008/07/discussion-paper-2008-9/.

[16] Fontana, G. (2004). Hicks on monetary theory and history: money as endogenous money. Cambridge Journal of Economics, 28(1), 73-88. doi: https://doi.org/10.1093/cje/28.1.73.

[17] Fung, B. S. C., \& Halaburda, H. (2016). Central Bank Digital Currencies: A Framework for Assessing Why and How. Bank of Canada Staff Discussion Paper 2016-22. https: //www.bankofcanada.ca/2016/11/staff-discussion-paper-2016-22/.

[18] Fung, B., Molico, M., and Stuber, G. (2014). Electronic Money and payments: Recent developments and issues. Bank of Canada Discussion Paper 2014-2. Bank of Canada. https://www.bankofcanada.ca/2014/04/discussion-paper-2014-2/.

[19] Fung, B., Huynh, K. P., \& Stuber, G. (2015). The use of cash in Canada. Bank of Canada Review, (Spring), 45-56. https://www.bankofcanada.ca/wp-content/uploads/2015/ 05/boc-review-spring15-fung.pdf.

[20] Galesi, A., Nuño, G., \& Thomas, C. (2017, March 2). The natural interest rate: concept, determinants and implications for monetary policy. Analytical Articles 2017. Banco de España. https://www.bde.es/f/webbde/SES/Secciones/Publicaciones / InformesBoletinesRevistas/ArticulosAnaliticos/2017/T1/files/beaa1701-art7e. pdf.

[21] Grym, A., Heikkinen, P., Kauko, K., \& Takala, K. (2017). Central bank digital currency. BoF Economics Review, 5. Bank of Finland. https://helda.helsinki.fi/bof/handle/ $123456789 / 14952$.

[22] Haldane, A. (2015, September 18). How low can you go? Speech. Portadown Chamber of Commerce, Northern Ireland. Bank of England. https:/ / www.bankofengland.co. uk/speech/2015/how-low-can-you-can-go.

[23] He, D., Leckow, R., Haksar, V., Griffoli, T. M., Jenkinson, N., Kashima, M., Khiaonarong, T., Rochon, T., \& Tourpe, H. (2017). Fintech and financial services: initial considerations. IMF Staff Discussion Note SDN/17/05. International Monetary 
Fund. https://www.imf.org/en/Publications/Staff-Discussion-Notes/Issues/2017/ 06/16/Fintech-and-Financial-Services-Initial-Considerations-44985.

[24] Jyrkönen, H., \& Paunonen, H. (2003). Card, Internet and mobile payments in Finland. Bank of Finland Discussion Paper, 8. Bank of Finland. https://helda.helsinki.fi/bof/ bitstream/handle/123456789/7655/116218.pdf?sequence=1\&isAllowed=y.

[25] Ketterer, J. A., \& Andrade, G. (2016). Digital central bank money and the unbundling of the banking function. Discussion Paper IDB-DP-449. Inter-American Development Bank. https://publications.iadb.org/en/ digital-central-bank-money-and-unbundling-banking-function.

[26] Kocherlakota, N. R. (1998). Money is memory. Journal of Economic Theory, 81(2), 232-251. doi: https://doi.org/10.1006/jeth.1997.2357.

[27] Mercatanti, A., \& Li, F. (2014). Do debit cards increase household spending? Evidence from a semiparametric causal analysis of a survey. The Annals of Applied Statistics, $8(4), 2485-2508$.

[28] Mersch, Y. (2017a, January 16). Digital base money: An assessment from the ECB's perspective. Speech at the Farewell Ceremony for Pentti Hakkarainen, Deputy Governor of Suomen Pankki - Finlands Bank, Helsinki. https://www.ecb.europa.eu/ press/key/date/2017/html/sp170116.en.html.

[29] Mersch, Y. (2017b, April 18). Why Europe still needs cash. Project Syndicate. https://www.project-syndicate.org/commentary/ europe-new-cashless-payment-methods-by-yves-mersch-2017-04?barrier= accesspaylog.

[30] Meaning, J., Dyson, B., Barker, J., \& Clayton, E. (2018). Broadening narrow money: monetary policy with a central bank digital currency. Staff Working Paper No. 724. Bank of England. https:/ / www.bankofengland.co.uk/working-paper/2018/ broadening-narrow-money-monetary-policy-with-a-central-bank-digital-currency.

[31] Nuño, G. (2018, July 30). Monetary policy implications of central bank-issued digital currency. Economic Bulletin 3/2018: Analytical Articles. Banco de España. https:/ /www. bde.es/f/webbde/SES/Secciones/Publicaciones/InformesBoletinesRevistas/ ArticulosAnaliticos/2018/T3/Files/beaa1803-art21e.pdf.

[32] Østbye, P. (n.d.). Cryptocurrencies: Monetary system consequences and regulatory response [PowerPoint slides], not published. Norges Bank.

[33] Plouffe, C. R., Vandenbosch, M., \& Hulland, J. (2000). Why smart cards have failed: looking to consumer and merchant reactions to a new payment technology. International Journal of Bank Marketing, 18(3), 112-123. doi: https:/ / doi.org/10.1108/02652320010339662.

[34] Riksbank, S. (2017, September). The Riksbank's e-krona project. Report, 1. Sveriges Riksbank. https://www.riksbank.se/en-gb/payments--cash/e-krona/ e-krona-reports/e-krona-project-report-1/.

[35] Rogoff, K. (2017). Dealing with monetary paralysis at the zero bound. Journal of Economic Perspectives, 31(3), 47-66. doi: 10.1257/jep.31.3.47.

[36] Schnabel, I., \& Shin, H. S. (2018). Money and trust: lessons from the 1620 s for money in the digital age. BIS Working Papers No 698. Bank for International Settlements. https://www.bis.org/publ/work698.htm.

[37] Shin, H. S. (1996). Comparing the robustness of trading systems to higher-order uncertainty. The Review of Economic Studies, 63(1), 39-59. doi: https://doi.org/10.2307/2298114.

[38] Wadsworth, W. (2018, April). What is digital currency? Reserve Bank of New 
Zealand Bulletin, 81(3). https://www.rbnz.govt.nz/research-and-publications/ reserve-bank-bulletin/2018/rbb2018-81-03.

[39] Wilkins, C. (2014, November 13). Money in a digital world. Wilfrid Laurier University, Waterloo, Ontario. https://www.bankofcanada.ca/2014/11/money-digital-world/.

[40] Witmer, J., \& Yang, J. (2015). Estimating Canada's effective lower bound. Bank of Canada Staff Analytical Note 2015-2. Bank of Canada. https:/ / www.bankofcanada.ca/ 2015/12/staff-analytical-note-2015-2/.

[41] Yeyati, E. L. (2006). Financial dollarization: evaluating the consequences. Economic Policy, 21(45), 62-118. doi: https://doi.org/10.1111/j.1468-0327.2006.00154.x.

[42] Zurbrügg, F. (2017, February 27). Cash - tried and tested, and with a future. Speech to the World Banknote Summit. Swiss National Bank. https:/ /www.snb.ch/en/mmr/ speeches/id/ref_20170227_zur/source/ref_20170227_zur.en.pdf. 
this page intentionally left blank 